\title{
THE EFFECT OF MESTRANOL AND LYNOESTRENOL ON THE SENSITIVITY OF THE ISOLATED RAT UTERUS TO THE INHIBITORY ACTION OF SYMPATHOMIMETIC AGENTS
}

\author{
A. ABDEL-AZIZ,* A. GHAZAL AND TAHIA DAABEES \\ Department of Pharmacology, Faculty of Pharmacy, University of Alexandria, \\ Alexandria, Egypt Arab Republic
}

(Received 25th March 1974)

\begin{abstract}
Summary. The effect of oral treatment of rats for 12 consecutive days with the contraceptive steroids, mestranol $(0.08 \mathrm{mg} / \mathrm{rat} /$ day $)$ and lynoestrenol ( $2.5 \mathrm{mg} / \mathrm{rat} / \mathrm{day})$, separately or in combination, on the sensitivity of the isolated spontaneously contracting rat uterus to the inhibitory action of isoprenaline, adrenaline and noradrenaline was investigated. The sensitivity to isoprenaline did not change significantly after any of the hormonal treatments. The sensitivity to adrenaline was significantly reduced after treatment with mestranol and lynoestrenol separately and together. Only mestranol treatment also resulted in a significant decrease in sensitivity to noradrenaline while the decrease after lynoestrenol or mestranol + lynoestrenol was not significant. Treatment with only one or with a combination of the steroids resulted in the appearance of excitatory $\alpha$-adrenoceptors which most probably contributed to the decrease in the sensitivity of the uterus to the inhibitory action of the sympathomimetic agents.
\end{abstract}

The reactivity of the isolated rat uterus to the inhibitory action of some sympathomimetic agents depends on the types of adrenoceptors, the rate of binding, the enzymatic inactivation and the functional state of the uterus (see AbdelAziz \& Bakry, 1973). After oestrogen treatment and during early pregnancy, there is a decrease in the sensitivity of the isolated rat uterus to some sympathomimetic agents (Abdel-Aziz \& Bakry, 1973).

The present investigation deals with the effect of treatment with two contraceptive steroids, mestranol and lynoestrenol, on the sensitivity of the isolated rat uterus to the inhibitory action of some sympathomimetic agents.

Forty virgin female albino rats with a mean body weight of $155 \pm 6.0 \mathrm{~g}$ were allocated equally to four groups. The animals selected showed regular oestrous cycles. The contraceptive steroids were suspended in $0.5 \%(\mathrm{w} / \mathrm{v})$ carboxymethylcellulose (CMC) and oral treatment with $0.2 \mathrm{ml} \mathrm{GMC}$ /day was continued for 12 consecutive days. The first group received $0.08 \mathrm{mg}$ mestranol $/ \mathrm{rat} /$ day, the second group received $2.5 \mathrm{mg}$ lynoestrenol/rat/day and the third

* Present address: Department of Pharmacology, Faculty of Medicine, University of Aleppo, Aleppo, Syrian Arab Republic. 
group received 0.08 mestranol $+2.5 \mathrm{mg}$ lynoestrenol/rat/day. The fourth group served as controls and received corresponding volumes of $0.5 \% \mathrm{CMC}$. Treatment in each group started when the animals were in oestrus. Vaginal smears were examined daily throughout the period of treatment. The dosage and duration of treatment ensured a maximal contraceptive effect (Goldzieher, Moses \& Ellis, 1962; Overbeek, Madjerek \& de Visser, 1962; Gardner, Gnoj, Watnick \& Gibson, 1964).

The isolated spontaneously contracting rat uterus was prepared essentially as described by Tothill (1965). The uterus was suspended in Locke solution at $37^{\circ} \mathrm{C}$ in a bath of $20-\mathrm{ml}$ capacity and the bathing fluid was gassed with a mixture of $95 \% \mathrm{O}_{2}: 5 \% \mathrm{CO}_{2}$. Uteri suspended under such conditions showed fairly regular rhythmic contractions. The mean concentration of adrenaline,

Table 1. Effect of treatment with mestranol, lynoestrenol and their combination on the sensitivity of the rat uterus to the inhibitory action of sympathomimetic agents

\begin{tabular}{|c|c|c|c|}
\hline \multirow{2}{*}{$\begin{array}{l}\text { Treatment } \\
\text { group }\end{array}$} & \multicolumn{3}{|c|}{$\begin{array}{c}\text { Mean concentration }(n g / m l)+\text { S.E. of agonist } \\
\text { causing } 50 \% \text { inhibition }\end{array}$} \\
\hline & Noradrenaline & Adrenaline & Isoprenaline \\
\hline Controls* & $49 \cdot 30 \pm 7 \cdot 90(6)$ & $0.44 \pm 0.05$ & $0.28 \pm 0.07(6)$ \\
\hline $\begin{array}{l}\text { Mestranol } \\
\text { alone }\end{array}$ & $\begin{array}{c}122 \cdot 20 \pm 9 \cdot 0(7) \\
P\end{array}$ & $\begin{array}{c}1.96 \pm 0.29(7) \\
P<0.001\end{array}$ & $\begin{array}{c}0.34 \pm 0.08 \\
P>0.05\end{array}$ \\
\hline $\begin{array}{l}\text { Lynoestrenol } \\
\text { alone }\end{array}$ & $\begin{aligned} 55.40 & \pm 2.90 \\
P & >0.05\end{aligned}$ & $\begin{array}{c}0.84 \pm 0.10(7) \\
P<0.005\end{array}$ & $\begin{array}{c}0.27 \pm 0.06(6) \\
P>0.05\end{array}$ \\
\hline $\begin{array}{l}\text { Mestranol } \\
\text { +lynoestrenol }\end{array}$ & $\begin{aligned} 60.60 & \pm 3.20(7) \\
P & >0.05\end{aligned}$ & $\begin{aligned} 1 \cdot 27 & \pm 0.22(9) \\
P & <0.01\end{aligned}$ & $\begin{aligned} 0.27 & \pm 0.04(6) \\
P & >0.05\end{aligned}$ \\
\hline
\end{tabular}

Numbers in parentheses indicate the number of uterine horns used. The $P$ values indicate the level of the significance of differences between the means of control and treated animals.

* Control rats were killed while in oestrus.

noradrenaline or isoprenaline which resulted in a $50 \%$ inhibition of the amplitude of the myogenic contractions was determined as described by Abdel-Aziz \& Bakry (1973). Not more than two sympathomimetic agents were tested on one uterine horn and only half the number of uterine horns in each group were used for testing sensitivity to sympathomimetic agents. In some experiments, some of the uterine horns were rejected because they failed to develop regular spontaneous contractions. The significance of the difference between means was determined using Student's $t$ test. The test for the presence of excitatory $\alpha$-adrenoceptors was carried out as described by Abdel-Aziz \& Bakry (1972). For this purpose, the remaining ten uterine horns in each treatment group as well as some of the uterine horns used in the tests of sensitivity were used. The agonists, adrenaline or noradrenaline, were added in concentrations which caused inhibitory effects on the rat uterus. After washing, propranolol, known to block $\beta$-adrenoceptors, was added in a concentration of $1.0 \mu \mathrm{g} / \mathrm{ml}$ for $10 \mathrm{~min}$. The previous concentration of each agonist was then retested in the presence of propranolol. In the presence of excitatory $\alpha$-adrenoceptors, adrenaline and noradrenaline resulted in an increase in the tone and/or 
the amplitude of the myogenic contractions. In some experiments, the nature of the excitatory adrenoceptors was checked by phenoxybenzamine, $1.0 \mu \mathrm{g} / \mathrm{ml}$, as described by Abdel-Aziz \& Bakry (1972).

At autopsy, the vaginal smear from animals treated with mestranol consisted mainly of cornified epithelial cells which were associated in a few rats with some cells with round nuclei. Those treated with lynoestrenol had a smear which consisted mainly of leucocytes accompanied by cells with round nuclei and a few cornified cells. The group treated with mestranol plus lynoestrenol had a smear consisting of almost equal numbers of cornified and epithelial cells with round nuclei as well as a moderate number of leucocytes. The epithelial cells with round nuclei in vaginal smears of rats treated with lynoestrenol or with mestranol+lynoestrenol were generally smaller in size than those observed in smears from control animals.

The sensitivity of the rat uterus to the inhibitory action of isoprenaline was not significantly changed by treatment with mestranol, lynoestrenol or the combined steroids, but the sensitivity to the inhibitory effect of adrenaline was significantly decreased (Table 1). The decrease in the sensitivity to the inhibitory action of noradrenaline was significant only after mestranol. Under the experimental conditions used, it was not possible to demonstrate excitatory $\alpha$-adrenoceptors in uteri obtained from control rats in oestrus. In the group treated with mestranol, in the absence of propranolol, adrenaline $(0.8$ to $2.7 \mathrm{ng} / \mathrm{ml}$ ) and noradrenaline (115 to $170 \mathrm{ng} / \mathrm{ml}$ ) resulted in inhibition of uterine contraction. In the presence of propranolol, the inhibitory action of adrenaline was blocked with no excitatory action but the action of noradrenaline was reversed to an excitatory one in nine out of fifteen uterine horns. In the group treated with lynoestrenol, the inhibitory action of adrenaline $(0.6$ to $1.3 \mathrm{ng} / \mathrm{ml})$ was blocked when the agonist was added after propranolol, while the inhibitory effect of noradrenaline $(40$ to $60 \mathrm{ng} / \mathrm{ml}$ ) was reversed to an excitatory action in three out of fifteen uterine horns when added after propranolol. In three out of twelve uterine horns from rats treated with mestranol+ lynoestrenol, the addition of noradrenaline $(50$ to $70 \mathrm{ng} / \mathrm{ml}$ ), in the absence of propranolol, resulted in an excitatory action. In the presence of propranolol, the inhibitory action of adrenaline $(0.6$ to $2 \mathrm{ng} / \mathrm{ml})$ was blocked but that of noradrenaline ( 50 to $70 \mathrm{ng} / \mathrm{ml}$ ) was reversed to an excitatory action in seven out of twelve uterine horns. Phenoxybenzamine antagonized the excitatory effects of noradrenaline.

The changes in the sensitivity of the rat uterus to the inhibitory action of some sympathomimetic agents may to some extent depend on the appearance of excitatory $\alpha$-adrenoceptors (Abdel-Aziz \& Bakry, 1973). In the present study, the sensitivity of the rat uterus to the inhibitory action of isoprenaline, a dominant $\beta$-adrenoceptor agonist, did not show any significant change following treatment with the contraceptive steroids. This may indicate that such treatment did not affect the sensitivity or the population of the uterine inhibitory $\beta$-adrenoceptors. The changes in the sensitivity of the rat uterus to the inhibitory action of adrenaline, known to act on both $\alpha$ - and $\beta$-adrenoceptors and that of noradrenaline, a dominant $\alpha$-adrenoceptor agonist, following treatment with oral contraceptive steroids, might partly be attributed to the appearance of excitatory $\alpha$-adrenoceptors. The existence of such receptors would tend to 
antagonize the inhibitory action of sympathomimetic agents acting mainly through $\alpha$-or $\alpha$-plus $\beta$-adrenoceptors. Excitatory $\alpha$-adrenoceptors are reported to exist in conditions associated with elevated oestrogen levels (Tothill, 1967; Butterworth \& Randall, 1970; Abdel-Aziz \& Bakry, 1972). The excitatory adrenoceptors observed in the present work are of the $\alpha$-type as they were blocked by phenoxybenzamine.

The vaginal smears of the rats treated with mestranol showed the expected induced oestrous state due to the oestrogenic activity of this steroid and many excitatory $\alpha$-adrenoceptors were found in rats treated with this steroid. By contrast, lynoestrenol, in the dose used, was shown to possess a weak oestrogenic activity in addition to a dominant progestational action. The weak oestrogenic activity of lynoestrenol has also been reported by several workers (Overbeek et al., 1962; Okada, Amatsu, Ishihara \& Tokuda, 1964; Paulsen, 1965). It seems possible that the dominant progestational action of lynoestrenol is responsible for the failure of the appearance of excitatory $\alpha$-adrenoceptors in the majority of rats treated with this steroid. This would also explain the finding that the decrease in the sensitivity of the rat uterus to the inhibitory action of adrenaline and noradrenaline was the least marked following treatment with lynoestrenol. The combined treatment with mestranol plus lynoestrenol resulted in the appearance of excitatory $\alpha$-adrenoceptors in more than $50 \%$ of the rats but the decrease in the sensitivity of the uterus to the sympathomimetic agents was less marked than that obtained with mestranol alone. From this, it can be concluded that the progestational effect of lynoestrenol tends to antagonize the effect of mestranol on the inhibitory action of some sympathomimetic agents on the uterus.

Factors other than the appearance of $\alpha$-adrenoceptors may also contribute to the changes in the sensitivity of the rat uterus to the inhibitory action of sympathomimetic agents. Such factors include the changes in the degree of uptake or physiological binding, changes in the enzymatic inactivation of sympathomimetic agents as well as the changes produced by the contraceptive steroids on the properties of the myometrium.

\section{REFERENGES}

ABdel-Aziz, A. \& BAKRY, N. (1972) The nature of the adrenoceptors in the post-partum rat uterus. Br. F. Pharmac. Chemother. 45, 504.

ABdel-Aziz, A. \& BAKRY, N. (1973) The reactivity of the rat uterus to sympathomimetics during the oestrous cycle and pregnancy and after parturition. F. Reprod. Fert. 35, 217.

Butterworth, K. R. \& RANDALL, M. J. (1970) The effects of $\alpha$ - and $\beta$-adrenoceptor blocking agents on the response of the rat uterus to catecholamines throughout the oestrous cycle. Br. F. Pharmac. Chemother. 40, 160p.

Gardner, J. N., Gnoj, O., Watnick, A. S. \& Gibson, J. (1964) New contraceptive agents with high activity in rats. Steroids, $\mathbf{4}, \mathbf{8 0 1}$.

Goldzieher, J. W., Moses, L. E. \& Ellis, L. T. (1962) Study of norethindrone in contraception. 7. Am. med. Ass. 180, 359.

Okada, H., Amatsu, M., Ishihara, C. S. \& TOKUdA, G. (1964) Gonversion of some synthetic progestins to estrogens. Acta endocr., Copenh. 46, 31.

Overbeek, G. A., MADJEREK, Z. \& DE VISSER, J. (1962) The effect of lynestrenol on animal reproduction. Acta endocr., Copenh. 41, 351.

Paulsen, G. A. (1965) Progesterone metabolism: special references to estrogenic pathways. Metabolism, $14,313$.

TотнгцL, A. (1965) The effect of four monoamine oxidase inhibitors on the rat uterus. Br. F. Pharmac. Chemother. 25, 217.

ToтнiLl, A. (1967) Investigation of adrenaline reversal in the rat uterus by the induction of resistance to isoprenaline. Br. F. Pharmac. Chemother. 29, 291. 